\title{
TAUHID DAN ETIKA LINGKUNGAN: Telaah atas Pemikiran Ibn 'Arabī
}

\author{
Ahmad Munji \\ Mahasiswa Pascasarjana \\ Universitas Islam Negeri (UIN) Walisongo Semarang \\ e-mail: amunji87@yahoo.co.id
}

\begin{abstract}
Tauhìd (monotheism) affirms that God has created man most excellent among the creatures with the aim to serve Him. Proof of service must be proved by maintaining the best possible environment as He wills. It will consequences which bring up the ethics that guide humans to interact with their environment. Therefore, the relationship of Tauhìd and ethics as good and bad links or ethical character that relies heavily on clean and dirty soul and reflect the quality of faith (īmān) and Tauhìd (monotheism) itself. This article aims to elaborate on the relationship of Tauhìd with mindset, because mindset is a soul activity that requires imagination in many ways and requires a balance; Tauhìd relationship with the pattern of attitudes; patterns of attitude is the basic concept of a person's behavior; relationship between Tauhìd and behavioral patterns ('amal). 'Amal is a reflection of a very concrete. From this pattern can be described as follows: Tauhìd produces ethics, and ethics produces behavior ('amal). The pattern of this relationship in real life can be seen, among other things, how human beings interact with other God's creatures (environment).
\end{abstract}

Abstrak:Tauhịd menegaskan bahwa Tuhan telah menciptakan manusia yang paling baik diantara para makhluk dengan tujuan untuk mengabdi kepada-Nya. Bukti pengabdian harus dibuktikan dengan menjaga lingkungan sebaik-baiknya sebagaimana yang dikehendaki-Nya. Konsekuensi dari ini akan memunculkan etika yang memandu manusia dalam berinteraksi dengan lingkungannya. Sebab, hubungan Tauhīd dan etika seperti keterkaitan baik dan buruknya akhlak atau etika yang sangat bergantung pada bersih dan kotornya jiwa dan 
mencerminkan kualitas dari iman dan tauhid itu sendiri. Artikel ini bertujuan mengelaborasi hubungan Tauhīd dengan pola pikir, karena pola pikir adalah aktivitas jiwa yang membutuhkan keseimbangan; hubungan Tauhīd dengan pola sikap; pola sikap adalah konsep dasar dari sebuah perilaku seseorang; hubungan antara Tauhīd dan pola perilaku ('amal). 'Amal merupakan cerminan yang sangat kongkrit. Dari sini pola ini dapat digambarkan sebagai berikut: Tauhīd menghasilkan etika, dan etika menghasilkan perilaku ('amal). Pola hubungan ini dalam kehidupan riil dapat dilihat, antara lain, bagaimana manusia berinteraksi dengan makhlukmakhluk Tuhan yang lain (lingkungan).

Keywords: Tauhīd, 'amal, ethic, Ibn 'Arabī, Allāh, enviromenment.

\section{A. Pendahuluan}

Tauhid menegaskan bahwa Tuhan telah menciptakan manusia yang paling baik diantara para makhluk dengan tujuan untuk mengabdi kepada-Nya. ${ }^{1}$ Amanat dari Tuhan tersebut merupakan pemenuhan unsur etika dari kehendak Ilahi yang sifatnya harus direalisasikan dengan kemerdekaan, dan manusia adalah satusatunya mahluk yang dapat melakukan itu. Tanggung jawab yang diberikan sama sekali tidak mengenal batas, mencakup segala unsur secara universal. Karena manurut al-Quran, tidak satupun makhluk Tuhan yang mampu memikul amanat tersebut kecuali manusia yang merasa mampu melaksanakannya. ${ }^{2}$ Ketika kehendak Ilahi direalisasikan dengan hukum alam, hal tersebut tidaklah bersifat moral, melainkan elemental. ${ }^{3}$ Namun sifat kebebasan bertindak dalam rangka mematuhi perintah Tuhan inilah yang menjadikan bersifat moral.Berkaitan dengan ini, maka bertauhid meniscayakan beretika atau bermoral yang mencerminkan kedalaman tauhid itu sendiri. Jika tauhidnya baik, dapat dipastikan etikanya pastilah baik.

Menurut al-Rāzī, bahwa hubungan tauhid dan etika seperti keterkaitan baik dan buruknya akhlak atau etika yang sangat 
bergantung pada bersih dan kotornya jiwa dan mencerminkan kualitas dari iman dan tauhid itu sendiri. ${ }^{4}$ Artinya keduanya bagaikan kesatuan yang tak terpisahkan integrated.Dalam hal ini, setidaknya menuai cabang penting, diantaranya: pertama, hubungan tauhid dengan pola pikir, karena pola pikir adalah aktivitas jiwa yang memerlukan khayal dalam berbagai hal dan membutuhkan keseimbangan. ${ }^{5}$ Kedua, hubungan tauhid dengan pola sikap; pola sikap adalah konsep dasar dari sebuah perilaku seseorang. Ketiga, hubungan antara tauhid dan pola perilaku, ini dapat kita maklumi, mengingat 'amal merupakan cerminan yang sangat kongkrit. Dari sini pola ini dapat digambarkan sebagai berikut: tauhid menghasilkan etika, dan etika menghasilkan perilaku ('amal). Pola hubungan ini dalam kehidupan riil dapat dilihat, antara lain, bagaimana manusia berinteraksi dengan makhluk-makhluk Tuhan yang lain.

Sebagai makhluk hidup, populasi manusia terus berkembang setiap saatnya. Dan, pada gilirannya perkembangan ini memberi implikasi negatif terhadap kualitas interaksi dengan mahluk-mahluk lain. McElroy menyebutkan kebutuhan manusia-sebagai salah satu penghuni bumi- terhadap sumberdaya alam menyebabkan banyak kerussakan, diantaranya adalah pemanasan suhu bumi, pencemaran tanah, air dan udara. ${ }^{6}$ Menguatkan apa yang disampaikan McElroy, menurut Mujiono pelaksanaan ekonomi industri dewasa ini terjebak pada kemakmuran materialisme hedonistik dan energi berkelimpahan, namun melupakan keterbatasan sumber daya alam.7Dengan kata lain, manusia dan perkembangan industrinya menjadi"perusak" planetnya sendiri sehingga krisis lingkungan terjadi di berbagai belahan bumi.

Menurut Evanof-sebagaimana dikutip oleh Suwito-krisis ekosistem yang terjadi merupakan akibat dari ketidakseimbangan antara diri (self), kepentingan publik (society), dan hak hidup lingkungan(nature). ${ }^{8}$ Sementara Nasr melihat bahwa sekularisasi 
kosmoslah yang menjadi pemicu utama manusia untuk melakukan eksploitasi takterbatas kepada alam, dengan agenda utama pemenuhan hajat hidup manusia yang serakah dan rakus.

Melihat kenyataan ini, muncul banyak keprihatinan dari kalangan ilmuan dari berbagai disiplin ilmu. Sebut saja Mc Kibben dalam tulisannya yang berjudul The end of Nature. ${ }^{9}$ Sementara paska Deklarasi Stockholm pada Juni 1972, Agama-agama besar dunia juga didorong untuk berupaya menopang kesadaran konservasi lingkungan dengan cara melakukan eksplorasi ajaran-ajarannya dan mengejawantahkan dalam kehidupan yang ramah lingkungan. Karena itu, muncullah karya-karya yang ditulis oleh para pakar mengenai lingkungan hidup, antara lain karya Chapel dan Turner. ${ }^{10}$ Arne Naes dengan teori "deep ecology" juga layak disebut sebagai penggerak konservasi lingkungan. ${ }^{11}$ Sementara dari sarjana muslim, gagasan Islam ramah lingkungan juga disuarakan oleh Seyyed Hossein Nasr, ${ }^{12}$ Yusuf Qardhawi. ${ }^{13}$ Dalam kontek ke-indonesiaan nama-nama seperti Mujiono ${ }^{14}$ dan Swito NS$^{15}$ juga layak disebut sebagai akademisi yang menyuarakan solusi dari krisis lingkungan menggunakan kacamata agama.Berangkat dari semangat menyuarakan Islam yang ramah lingkungan, penulis akan mencoba mengeksplorasi pemikiran sufi agung Ibn 'Arabī mengenai isu tersebut.

\section{B. Tentang Ibn ‘Arabī}

Nama lengkap Ibn 'Arabī adalah Muḥammad ibn 'Ali ibn Muhammad ibn Aḥmad Abdillāh al-Hatīmī, seorang putra dari Abdillāh ibn Hatīmī al-Ṭa'i. ${ }^{16}$ Ia terkenal dengan beberapa panggilan "laqab", diantaranya Syaikh Akbar17, Muḥyi al-Dīn dan putera Plato. ${ }^{18}$ Di kalangan Timur beliau lebih masyhur dengan al-Hatīmī, ini untuk membedakan antara beliau dan seorang qādī, Abū Bakr ibn 'Arabī. Menurut Kautsar pada saat itu memang ada dua Ibn 'Arabī, keduanya sama-sama dari Andalusia. Yang pertama Abū Bakr 
Muḥammad ibn 'Arabī (hakim), dan yang kedua Muhammad ibn 'Arabī, sufi terkenal yang dimaksud dalam tulisan ini.

Ibn 'Arabī lahir di Mursia, kota kecil yang terletak di barat daya Andalusia-sebuah kota yang dirintis oleh kaum muslimin pada masa daulah bani Umayah. Ia dilahirkan pada tanggal 17 Ramadhan $560 \mathrm{H}$, bertepatan dengan 28 Juli 1165. Bapaknya Abū'Alī ibn Muhammad adalah seorang ulama interdisipliner, yang menguasai bidang, hadis dan tasawuf. Sementara kakeknya adalah pakar dan qā Andalusia. Ibn 'Arabī kecil tumbuh dibawah pengawsan orangtuanya yang mapan secara ekonomi dan religius.

Ketika umur beliau menginjak delapan tahun Mursia mengalami krisis politik, hal ini menyebabkan Ibn 'Arabī ikut dengan orangtuanya pindah ke Isbiliyah-sekaran Sevila-, disanalah kemudian Ibn 'Arabī kecil tumbuh menjadi dewasa. Semenjak di Sevila, Ibn 'Arabī Menghabiskan masa mudanya untuk belajar beberapa disiplin ilmu, seperti hadist, fiqih, teologi dan filsafat skolastik dan cabang ilmu agama yang lain. ${ }^{19}$ Perlu diketahui, Sevila adalah satu pusat sufisme yang tidak kalah penting, dengan guru sufi terkemuka yang tinggal disana. Ibn 'Arabī adalah anak yang cerdas, Samsyuddīn ketika bercerita tentang Ibn 'Arabī mengatakan, dia adalah anak yang bakat menulis dan menyusun kalimat, cepat dalam menangkap pengetahuan. Setelah itu Ibn 'Arabīpindah ke Kordoba, dimana di kota itulah beliau bertemu dengan seorang guru besar filsafat Islam Ibn Rusyd, yang kebetulan pada saat yang sama Ibn Rusyd adalah hakim di Kordoba.

Ketika usianya memasuki tigapuluh tahun, Ibn 'Arabī berkeliling ke penjuru negeri Islam, sehingga beliau bertemu dengan sufi-sufi besar, seperti tercatat pada tahun 590 H Ibn 'Arabī untuk pertama kalinya meninggalkan semenanjung Iberia. Pada tahun itu beliau mengunjungi Tunisia dan bertemu dengan Ibn Qasī, pemimpin sufi yang melakukan pemberontakan kepada dinasti alMurabbațūn. ${ }^{20}$ Pada tahun berikutnya beliau mengunjungi Fez, 
disanalah beliau menulis karyanya yang berjudul al-Isrā'. Kemudian ia kembali ke Tunisia pada tahun $598 \mathrm{H}$. Selama di Tunisia itu beliau menyelesaikan karyanya Insa' al-Dawā'ir.21 Ketika situasi religiopolitis di Spayol memburuk Ibn 'Arabī melakukan perjalanan kedairah-dairah timur dunia Islam, diawali dari mesir dan selanjutnya beliau hijrah ke Makkah. Saat perjalanannya ke Makkah inilah merupakan fase pembentukan dirinya sebagai seorang sufi, dan hampir seperdua umurnya dihabiskan pada fase itu. Salah satu sisi yang paling menakjubkan dari perjalanan hidup Ibn 'Arabī adalah hasil karyanya. Osman Yahya Sebagaimana dikutip oleh Chittick, menyatkan bahwa Ibn 'Arabī menulis 700 buku, sementara karyanya yang berbentuk artikel berbilang 400 buah. $^{22}$

Ibn 'Arabī Mengahiri hidupnya pada 22 Rabì' al-Śani didamaskus. Didamaskuslah Ibn 'Arabī memilih mengahiri perjuangannya. Beliau dimakamkan di kaki bukit Qasiun dibagian utara kota Damaskus, tempat dimana sering menjadi tujuan ziarah kaum muslimin karena dianggap tempat yang disucikan semua nabi, khususnya al-Khidir. Sejak Syekh besar itu dimakamkan disana, tempat itu semakin banyak dikunjungi orang.

\section{Etika Lingkungan Berbasis Tauhid}

Dalam Tasawuf, etika merupakan hal yang prinsip, karena tasawuf seperti yang didefinisikan oleh al-Junaid adalah akhlaq (etika), barang siapa yang semakin beretika maka dialah yang semakin bertasawuf. Sementara etika adalah perilaku yang muncul dengan reflek tanpa harus berpikir. ${ }^{23}$ Menurut Ibn 'Arabīwatak etika dalam Islam itu tidak terbatas pada hubungan manusia dengan sesama. Lebih dari itu etika bertitik tolak pada faham universalitas islam tentang tuhan "rab", alam "al-kaun", dan manusia "al-insan". Hubungan yang harmonis dan "akrab" dari dua unsur yang terahir inilah yang akan menghantarkan pada ketenangan universal. Kestabilan antarmanusia dan alam akan memberikan ketenangan 
manusia dalam melewati hidup, yang akan mampu mengantarkannya kepada Tuhan.

Bagi Ibn 'Arabī, berangkat dari hadis "Aku adalah harta terpendam, Aku ingin dikenal karena itu aku menciptakan makhluk agar Aku dikenal",24 Allah merindukan diri-Nya sendiri sehingga Dia menciptakan alam semesta, kerinduan ini bertujuan agar Dia dikenal. Kata "ingin" dalam hadis menunjukan bahwa Tuhan menghendaki melihat diri-Nya sendiri, dan ketika Dia menyadari bahwa tidak mungkin melihat "diri-Nya" tanpa perantara (wasīlah), maka Tuhan menciptakan alam semesta. ${ }^{25} \mathrm{Hal}$ ini bisa dijadikan argumen bahwa ciptaan Tuhan adalah dimensi yang tak terpisahkan dari eksistensi Tuhan. Keberadaan alam yang unik dan teratur memberi isyarat tentang eksistensi sang pengatur, Tuhan pencipta alam.

Ketika kita memahami bahwa yang menjadi tujuan utama (main goal) penciptaan alam semesata adalah pengetahuan Tuhan tentang diri-Nya, maka hal ini menuntut manusia untuk mampu menegakkan kehendak Allah dan menerapkan semua ketetapanketetapan-Nya. Terhadap alam, manusia harus tetap menjaga kehendak Allah dan tetap mengawasi berbagai ketetapan-Nya atas alam. Bahkan Ibn 'Arabī menegaskan, alam dan segala isinya, meskipun wujudnya bermacam-macam padadasarnya satu, yaitu irādah (kehendak tuhan). ${ }^{26}$ Sumber ini bisa menjelaskan bahwa semua unsur alam semesta memiliki nilai dan manfaat sehingga menuntut kita untuk berbaik kepada alam.

Pandangan Ibn 'Arabī tentang alam nampaknya mempunyai titik temu dengan ilmu ekologi, dimana keduanya melihat tidak ada makhluk yang sia-sia diciptakan oleh Tuhan. Selain karena makhluk di muka bumi, baik tumbuh-tumbuhan, binatang maupun manusia, saling terkait dalam satu keutuhan lingkungan hidup. Keteraturan tata kelola tersebut juga dipandang sebagai isyarat eksistensi sang pencipta dan pengaturnya, Allah; dimana Tuhan sebagai realitas tertinggi, adalah tunggal, dan eksistensi selain Allah "mā siwā Allāh" 
berasal dari-Nya dan terhubung dengan-Nya. ${ }^{27}$ Alam dengan keanekaragamannya tidak lain sebagai manifestasi dari wujud yang satu. Logika yang digunakan antara alam dan wujud yang tunggal diilustrasikan melalui "wajah" dengan wajah yang ada pada beberapa cermin. Wujud yang tunggal bisa dilihat dalam beberapa cermin yang ada. Dalam pemahaman ini, sakralitas wujud yang tunggal terpantul dan mengalir pada wujud yang banyak. Hal senada juga disampaikan Nasr, pada dasarnya sufisme mengijinkan manusia memperlakukan alam sebagai hal yang sakral. Proses yang demikian melahirkan pemahaman bahwa melihat alam adalah melihat tuhan, karna alam adalah teofani tuhan.

Cara memandang alam seperti di atas merupakan ciri khas dari faham wahdat wujūd Ibn 'Arabī, yang melihat benar tidak hanya bersumber pada rasio tetapi juga mengakui kebenaran metafistik. Kedua faktor ini menjadi signifikan dalam penyusunan etika lingkungan dan proses peningkatan kesadaran berlingkungan. Bagi Ibn 'Arabī, menyaksikan keunikan alam dengan mata intelek "mata hati" adalah melihat alam, tidak semata-mata dipahami sebagai realitas "wujud" benda kasar, tetapi sebagai pertunjukan yang pada keunikan dan keanekaragamannya tercermin sifat-sifat ketuhanan yang sedang dibacakan oleh Tuhan. ${ }^{28}$ Lebih lanjut, Ibn 'Arabī mengilustrasikan alam sebagai al-Quran besar Mușhaf Kabïr, yang lembaran-lembarannya penuh dengan kata-kata penulisnya. Dalam mengomentari hal ini, Nasr memandang bahwa seni (art) dan ilmu (science) dalam islam didasarkan pada konsep tauhid. Berpikir kesatuan ini mengantarkan pada kesatuan Tuhan, yang mana kesatuanya semestanya merupakan wujud dari citra-Nya.

Mempertemukan etika lingkungan dengan etika Islam, sesungguhnya ada titik temu antara makna yang terkandung dalam perdamaian serta hakikatdasar dari etika Islam itu sendiri. Pada dasarnya hakikat dari etika Islam berkisar pada konsep tauhid (the concept of unity). Persatuan adalah bagian yang tidak terpisahkan 
dari konsep monoteisme Islam. Menurut konsep ini, kehidupan berasal dari kesatuan eksistensi yang pada dasarnya adalah manifestasi dari kesatuan Tuhan. Artikulasi Islam lā ilāha illāAllāh "tidak ada Tuhan selain Allah," adalah pernyataan dari konsep kesatuan yang menjadi dasar bagi semua keyakinan, hukumalamserta sosial—dan kehidupan itu sendiri. Semua ciptaan berakhir dan harus berkumpul di dalam kuasa Sang Pencipta. ${ }^{29}$ Pemahaman Islam tentang etika lingkunganyang didasarkan pada spirit makna tauhid ini memberikan implikasi pemikiran tentang kesatuan mendasar antara Allah dan semua eksistensi di alam ini. Kesadaran akan makna tauhid mengindikasikan manusia berada pada persatuan dan perdamaian tidak hanya dengan sesama manusia di samping juga dengan alam. Apabila kesadaran mengenai tauhid ini dilupakan, maka hubungan menjadi tidak lagi damai.Pandangan sufistik dalam hal ini secara tegas menyatakan tentang perdamaian berakar pada tauhid, konsep tauhid yang menjadi prinsip persatuan yang memberikan lahan subur bagi berkembangnya keimanan dan spiritualitas.

Pandangan-pandangan diatas menawarkan bagaimana mengimplementasikan konsep tauhid yang ramah lingkungan. Tauhid yang selama ini difahami mengesakan tuhan, perlu mengalami ekplorasi untuk digunakan dalam konsep-konsep sosial, budaya dan lingkungan hidup.Tauhid, kemudian merupakan sebuah konsepsi yang realitasnya memasuki kehidupan manusia di berbagai tingkatan, membentuk pemikiran Islam, spiritualitas, dan pada level praktek. Interpretasi terhadap implikasi dari tauhid membedakan hukum dan teologi serta filsafat, pemikiran sosial dan politik, ilmu pengetahuan, dan teosofi. Bagi Abdallah perluasan makna tauhid tidak diartikan sebagai bentuk penyimpangan tetapi justru sebuah tuntutan. ${ }^{30}$ Bahkan pemahaman ini memungkinkan dimensi mistik islam untuk bermain peran dalam membangun etika lingkungan yang lebih ramah. Dalam konteks ini, etika lingkungan yang berbasis 
tauhid bisa diartikan kesadaran sepiritual yang terejawantahkan dalam interaksi antar sistem wujud, terlebih pada lingkungan terdekat. Lingkungan dioptimalkan sebagai sarana untuk samapai pada Tuhan. Alam sebagai saran berzikir kepada Allah. Dengan kesadaran ini, individu akan memperlakukan lingkungan denga arif dan bijaksana, melihat alam sebagai partner bukan musuh yang wajib ditaklukan.

Tradisi sufi (tasawuf) menekankan bahwa Islam pada intinya merupakan sebuah pesan yang berisi tentang etika. ${ }^{31}$ Pesan ini berlaku untuk kedamaian batin, kepada masyarakat dan kosmos. Islam adalah proses kepasrahan kepada Allah, yang melalui proses tersebut manusia sebagai mikrokosmos dipersatukan dengan dengan semesta sebagai makrokosmos.Kepasrahan diri ini tidak hanya sebagai tujuan etika, akan tetapi juga merupakan sumber pengetahuan dan aktivitas. Melalui kepasrahan ini, beberapa bagian menjadi bersatu dengan keseluruhan. Makhluk datang untuk mengetahui Sang Pencipta, dan melalui Sang Pencipta, terwujudlah kesatuan eksistensi, waḥdat al-wujūd. Sebagaimana diungkapkan oleh Murata dan Chittick bahwa para sufi menegaskan manusia dan semua makhluk berbagi dalam kondisi eksistensialnya untuk menyerahkan kepada Tuhan. Spiritualitas manusia ditandai oleh terwujudnya kebijaksanaan (wisdom), keharmonisan dan keindahan dalam keragaman dan keutuhan alam.

\section{Relasi Tuhan, Alam, dan Manusia}

Dalam tradisi islam-yang merupakan rahim dari ajaran sufisme- memandang bahwa semua unsur dari alam semesta, baik yang di darat atau di laut, yang hidup atau yang mati memiliki manfaat dan diciptakan tanpa kesia-siaan ${ }^{32}$ dan bertasbih. ${ }^{33}$ Merupakan sebuah premis kebenaran bahwa semua mahluk bertsbih pada Allah. Kenyataan ini adalah riil metafisik"ghaib" yang tidak bisa diterima oleh tradisi keilmuan barat. Hal ini sebagaimana 
disinggung didepan bahwa kebenaran dalam tradisi sufisme tidak hanya bertumpu pada hal-hal yang masuk akal (rasional), tetapi juga mengakui kebenaran metafisik. Sehingga, relasi ekosistem bukan hanya berlaku hukum produsen dan konsumen, penyedia pangsa dan pemangsa sebagaimana dalam ekologi. Tetapi sufisme justru memiliki pandangan yang lebih holistik dan progresif. Alam menurut Ibn 'Arabī dapat berfusngsi sebagai ayat (tanda kebesaran Allah), media untuk pemenuhan kebutuhan konsumtif (intifa'), dan pemanis sebagai (zinah). ${ }^{34}$

Alam sebagai ayat (tanda kebesaran Allah) senantiasa dapat dioptimalisasikan sebagai bahan renungan "ta'amul" dan pelajaran "i'tibar", sehingga seseorang dapat sampai dan mendapatkan kebijaksanaan ilahiyah "al-hikmah al-ilahiyah". Dalam kasus ini, Ali Jumah melihat ada beberapa implikasi positif dari proses renungan "ta'amul" dan pelajaran "i'tibar" diantaranya, renuangan akan proses penciptaan alam semesta dan belajar dari umat-umat terdahulu yang keduanya dapat menghantarkan pada level keimanan yang lebih tinggi. 35

Ibn 'Arabī, sebagaimana dikutip oleh Nasr memandang antara al-Quran dan alam semesta memiliki kesamaan wujud. Yang pertama adalah wahyu yang diturukan dan diterjemahkan Muhammad dengan berbagai simbol tulisan dan kata yang terhimpun, sementara yang kedua adalah wahyu berbentuk kosmik "kauwn". ${ }^{36}$ Kedua ayat itu saling melengkapi. Salah satunya tidak bisa berfungsi dalam menyingkap kesucian dan realitas Tuhan tanpa dukungan dari yang lain.Islam memandang bahwa pada intinya alam merupakan teofani yang menyelubungi dan sekaligus menyingkap Tuhan. Kekayaan unsur alam yang tak terhitung merupakan teater Tuhan, yang menyingkap kebesaran Ilahiah tetapi pada saat yang sama juga menutupkebesaran itu bagi mereka yang mata hatinya belum dibutakan oleh ego yang sombong dan kecenderungan-kecenderungan penuh nafsu. ${ }^{37}$ 
Tuhan mengajak manusia untuk selalu mengingatnya dengan memikirkan dan memahami alam semesta ini.Sebagaimana alQur'an berulang kali menggarisbawahi, inspirasi spiritual untuk menopang keimanan mekanismenya dilakukan melalui pengamatan tajam terhadap alam, yang merupakan manifestasi tanda-tanda kebesaran Allah, ${ }^{38}$ sehingga manusia sebagai pengampu kekuasaan tuhan dibumi sudah waktunya untuk melihat alam semesta tidak hanya dengan mata, tetapi dengan akal dan pikiran untuk beranganangan, mengambil pelajaran, menimbang dan mengkoparasikan, menganalisa dan mendiskusikannya, yang pada gilirannya bisa membuka realitas tuhan pada eksistensi terdekat.

Relasi penting yang selanjutnya adalah alam sebagai pemenuhan kebutuhan "alaqat al-tașir wa al-intifä”'. Tidak sedikit aya-ayat al-Quran yang menjelaskan bahwa alam semesta ini dicipkatan untuk memenuhi kebutuhan manusia. ${ }^{39}$ Hal ini nyata di dalam realitas kehidupan. Tidak ada satupun yang memungkiri bahwa perkembangan populasi umat manusia selalu diikuti dengan peningkatan kebutuhan konsumtif, mulai dari kebutuhan pangan, tempat tinggal dan pemanfaatan yang lain. Pada dasarnya manusia dalam relasi ini sebagai elemen kecil dari sistem kehidupan. Maka, dalam hukum kausalitas keberadaan manusia sangat bergantung pada eksistensi kehidupan yang lain.

Kalaudirunut, kronologi kejadian manusia samapai pada kehidupan selalu membutuhkan eksistensi alam semesta. Sebut saja tanah, dari awal jasad manusia berasal dari mineral yang terkandung dalam tanah. Demikian juga manusia hidup ditanah. Sebagaian besar jenis makanan yang dikonsumsi manusia berasal dari tanah. Oleh karnanya, manusia pada hakikatnya adalah saripati tanah yang tidak bisa hidup tanpa tanah. ${ }^{40}$ Selain tanah, air juga merupakan partikel penting dalam penyusunan manusia. Air bahkan merupakan unsur utama penyusunan manusia, karena asal mula kehidupan dikatakan berawal dari air. ${ }^{41}$ Dari air lah awal mula kejadian semua eksistensi 
yang hidup, selanjutnya terjadilah kehidupan seperti tumbuhan, hewan dan manusia.

Seperti Tanah dan Air, partikel dari alam semesta yang lain seperti benda yang bernyawa dan tidak bernyawa, benda yang bergerak sampai tanaman dan hewan besar yang mengalami tumbuh kembang juga mendukung eksistensi manusia. Penjelasan inilah kemudian dikatakan oleh Ibn 'Arabī manusia adalah mikrokosmos. ${ }^{42}$ Argumentasi ini semakin menguatkan memang benar kalau alam semesta ini diciptkan untuk manusia. Namun, ada beberapa hal yang perlu digaris bawahi, pengertian "intifa"' atau mengambil manfaat dari eksistensi alam semesta ini mengenal batas dan pertimbangan. Sehingga, Ajaran Islam-sebagai agama monoteisme- mampu menyangkal kritik yang dilontarkan oleh Lynn White.

Dalam karyanya yang berjudul "The Historical Root of Our Ecological Crisis", White mengkritik habis cara pandang agamaagama monoteism-terutama Kristiani yang menjadi agamanyatentang penguasaan yang terlapau ekploitatif hingga mengakibatkan krisis lingkungan. Barangkali kritikan ini dilatarbelakangi oleh amanat ajaran Kristiani menjadi lahan subur bagi berkembangnya sans yang bersifat destruktif terhadap lingkungan. ${ }^{43}$ Bagi pengikut paham ini, agama-agama monoteisme dipandang tidak prolingkungan justru mendorong spirit ekploitasi.

Islam memang sebagai-rahim ajaran tasawuf- memang termasuk dalam agama-agama monoteisme, pada saat yang sama, islam juga memposisikan manusia sebagai pusat dari ekosistem "antroposentris" yang dilambangkan dengan simbol halifah. ${ }^{44}$ Kemudian dipertegas lagi bahwa semua ciptaan Tuhan ditundukan kepada manusia, ${ }^{45}$ implikasinya kesinambungan sistem alam semesta sangat bergantung pada moral khaliffah dibumi. Ada pesan untuk mengelolanya dengan penuh tanggungjawab, kesederhanaan "tawasut" dan pertimbangan "tawāzun". Bagi Ibn 'Arabī, tidak semua 
manusia bisa menyandang gelar khaliffah. Karna, peran "wakil" Tuhan di bumi hanya akan bermakna jika manusia mampu hidup damai dengan alam dan melestarikanya.46Yang diinginkan dari khilāfah adalah wakil, karena pada dasarnya alam semesta adalah milik Allah, sementara manusia hanya sebagai ekskutor, yang ruang geraknya dibatasi. Sehingga, manusia baik secara individu maupun kelompok tidak mempunyai hak mutlak untuk menguasai sumber daya alam, karena manusia hanya sebatas wakil. Sementara yang mempunyai hak mutlak untuk mengatur dan menguasai alam adalah Tuhan. Sebagai "wakil" manusia harus menjaga keberlangsungan ekosistem sebagai upaya menjaga amanat yang dititipkan.

\section{E. Penutup}

Pada dasarnya, Ibn 'Arabī tidak mempunyai konsep yang matang tentang etika lingkungan. Namun, dari paparan diatas minimal bisa kita fahami bahwa nilai-nilai tasawuf falsafi-sebagai dimensi mistikdalam Islam- yang bertumpu pada konsepwahdat alwujūd, mempunyai perhatian yang sangat dalam dan mendasar terhadap eksistensi lingkungan dan konservasinya.Artinya, pemahaman terhadap sistem wujud secara spiritual akan mengantarkan seseorang menjadi lebih dekat dengan penciptanya dan menjadi lebih arif dalm prilaku.

Dalam konteks konservasi lingkungan, tentunya cara pandang tasawuf falsafi ini sangat potensial untuk dijadikan langkah alternatif dalam proses mitigasi kesadaran berlingkungan. Hal ini karena pendekatan etika lingkungn yang berbasis tasawuf menawarkan solusi intergratif dalam memandang alam. Kesatuan hubungan antara Tuhan, alam dan manusia menjadai modal pemahaman bahwa merusak alam sama dengan merusak hubungan dengan Tuhan. Hubungan yang tidak sehat akan membuat unsur tertingi(Tuhan) dalam hubungan itu murka. 


\section{Catatan Akhir}

${ }^{1}$ QS. al-Żariyāt [51]: 56, "Dan aku tidak menciptakan jin dan manusia melainkan supaya mereka menyembah kepada-Ku."

${ }^{2}$ QS. al-Ahzab [33]: 72, "Sesungguhnya Kami telah mengemukakan amanat kepada langit, bumi dan gunung-gunung, maka semuanya enggan untuk memikul amanat itu dan mereka khawatir akan mengkhianatinya, dan dipikullah amanat itu oleh manusia. Sesungguhnya manusia itu Amat zalim dan Amat bodoh."

'Isma'il Raji al-Faruqi, Tauhid, Bandung: Penerbit Pustaka, 1988, h. 61 .

4Jarman Arroisi, "Integrasi Tauhid dan Akhlak dalam Pandangan Fakhruddin Ar-Razi", dalam Tsaqofah, Vol. 9, Nomor 2, 2013, Gontor, Institut Studi Islam Darussalam (ISID), h. 319.

${ }^{5}$ Abū 'Alī Aḥmad ilbn Muḥammad ibn Ya'qūb al-Rāzī, Tanzib alAkhlāq wa Tamhīr al-A'rāqī, Beirūt: Dār Maktabah al-Hayāt, 1398, h. 51.

6Tucker dan Grim,The Emerging Alliance World Religion and Ecology, Daedalus. 130,4, (2001), h. 2.

${ }^{7}$ Mujiyono Abdillah, Agama Ramah Lingkungan: Perspektif AlQur'an, Jakarta: Paramadina, 2001.

'Suwito NS, Eko-Sufisme: Konsep, Strategi dan Dampak, Purwokerto: STAIN Press, 2011, h. 3-4.

${ }^{9}$ Bill McKibben, The End of Nature, New York: Randon House, 1982.

${ }^{10}$ Christoper Key Chapel \& Mary Avelyn Turner, Hinduism and Echology, Cambrige: Harvard University Press, 2000.

${ }^{11}$ Arne Naes, Ecology, Community and Lifestyle, Outline of an Ecosophy, Cambridge: Canbridge University Press, 1989.

${ }^{12}$ Banyak karya-karyanya terkait dengan lingkungan, seperti The Encounter Man and Nature, California:California Press, 1984; Religion and The order of Nature, New York: Oxford University Press 1996; Seyyed Hossein Nasr, "Islam dan Krisis Lingkungan", Islamika, No. 3, Januari-Maret 1994.

13Yūsuf Qarḍawī, Ri'ayat al-Bi'ah fí Syarī'at al-Islām, Cairo: Dār alSyurūq, 2001.

${ }^{14}$ Mujiono Abdillah, Agama Ramah Lingkungan: Perspektif AlQur'an, Jakarta: Paramadina, 2001.

${ }^{15}$ Disertasinya berjudul, Eko-Sufisme: Konsep, Strategi dan Damapak, Purwokerto: STAIN Press, 2011. 
${ }^{16}$ Ta'i adalah sebuah kabilah kecil di kota Marsiah Andalusia. Lihat Mukri' al-Tilmisani, Nafhu al-Taiyib min Ghasni al-Andalus alRațib, Jil.. I, Beirūt:Dār Șadir, 1279, h. 410.

${ }^{17}$ Sejarawan Muslim menilai julukan ini tidak diperoleh dengan mudah, Ibn 'Arabī dianggap lebih dari layak untuk menyandang gelar ini, demikian karena kedalaman ilmunya yang yang hampir tidak terlampoi oleh tokoh lain sepanjang sejarah islam. Keterangan lebih jelas lihat 'Usmān Yahyya, Muallafat Ibn 'Arabī: Tārīkhuhu wa Tasnifuhu, Cairo: Dār al-Hidāyah, 1992, h. 135-144.

${ }^{18 B a l a t i u s, ~ I b n ~ ' A r a b i ̃: ~ H a y a ̄ t u h u ~ w a ~ M a z h a b u h u, ~ t e r j ~ A b d u l ~ a l-~}$ Rahman, Beirūt:Dār al-Qalam, 1979, h. 5.

${ }^{19}$ Basyīr Ghazālī, 'Umdat al-Tașawwuf al-Islām fì Mìzān alMustasyrikin, Kuffah: Maktabat Jami'ati al-Kuffah, tth, h 10.

${ }^{20}$ Ibn 'Arabī, Futūhāt, Juz IV, h. 129.

${ }^{21}$ Ibid., h. 98-99.

${ }^{22}$ William C. Chittick, Jalan Sufi, , terj. Ahmad Nijam dkk, Yogyakarta:Adipura, 2001, h. 8.

${ }^{23}$ Al-Ghazālī, Ihyyā' 'Ulūm al-Dīn, Jil. III, Beirūt: Dār al-Ma'ārif, tth, h. 53.

${ }^{24}$ Hadis ini tidak populer diantara ahli hadis, maka tidak heran Ibn Taimiyah meragukan kesahihannya. Lihat Fatawā Ibn Taimiyah, Beirūt:Dār al-'Arabiyah, 1398, h 132. Tetapi Ibn 'Arabī mengklaim ini sebagai hadis yang sahih; lihat: Ibn 'Arabī, Futūḥāt, jil. 2, h 399.

25Ibn 'Arabī, Fuṣūṣ al-Hikam, Beirūt: Dār al-Kutub al-Alamiyah, 2003, h. 120

26Ibn 'Arabī, Syajarat al-Kaun, Riyāḍ:Riyāḍ Abdi Allāh, 1985, h. 21.

${ }^{27}$ William Chittick, The Concept of Human Perfection dalam World and I, New York:New World Comunications, 1991, h. 500.

${ }^{28} \mathrm{Ibn}$ 'Arabī sering mengistilahkan alam sebagai al-Quran jumbo, "mușhafal-kabïr". Lihat: Futūḥāt al-Makiyah, Jil.. I, h. 158.

${ }^{29}$ Lutfi Rahman, Etika Perdamaian Islam: Telaah atas Pemikiran Maulana Wahiduddin Khan, Thesis S2 IAIN Walisongo, 2012,h. 43.

${ }^{30}$ Mudhofir Abdallah, "Argumentasi Konservasi Lingkungan dalam Perspektif Ekoteologi",Teologia: Jurnal Ilmu-ilmu Ushuluddin, Volume 22, Nomor 1, Januari, 2011, h. 29.

${ }^{31}$ Baihaqi, Sunan al-Kabīr Li al-Baihaqī, Jil. X, Beirūt: Dār al-Kutub al-'Alamiyah, 2003, h. 192.

${ }^{32} \mathrm{QS}$. al-Baqarah [2]: 26.

${ }^{33}$ QS. al-Anbiyā [21]:33, QS. Yā Sīn [36]:60, QS. al-Ḥadīd [57]:1. 
34Ibn 'Arabī,Futūhāt al-Makiyah, Jil.. I, h. 197.

${ }^{35}$ Ali Jum'ah, Riayat al-Qur'ān bi al-Huqūq al-Insān, Cairo: Dār alḤadīs, 2010, h. 79.

${ }^{36}$ SeyyedHossein Nasr, Intelegensi dan Spiritualitas Agamaagama. terj. Suharsono dkk, Jogja: Inisiasi Press, 2004, h 199; juga Ibn 'Arabī, Futūhāt al-Makiyah, Jil.. I, h 158.

${ }^{37}$ Ibn 'Ațā' Allāh, al-Hikam, Jaddah: tt, h 18

${ }^{38} \mathrm{QS}$. al-Baqarah [2]: 164.

${ }^{39}$ QS. al-Baqarah [2]: 2, QS. al-An'ām [6]:96, 97, QS. al-A'rāf [7]:10. ${ }^{40}$ Suwito NS, Eko-Sufisme, Purwokerto:Stain Press, 2011, h 84.

${ }^{41}$ QS. al-Anbiyā [21]: 30.

42Ibn 'Arabī, Fușūṣ al-Hikam, h 35

${ }^{43}$ Lynn White, The Historical Root of Our Ecological Crisis, Science Pdf, h. 1205.

${ }^{44} \mathrm{QS}$. al-Baqarah [2]:30.

${ }^{45}$ QS. al-Jāsiyah [45]:13.

"66Ibn 'Arabī,Fușūṣ al-Hikam, h. 41. 


\section{DAFTAR PUSTAKA}

Abdullah, Mudhofir, Argumen Konservasi Lingkungan dalam Prespektif Ekoteologi dalam Jurnal Teologia, Semarang, 2011.

Afifi, A.E, Filsafat Mistis Ibn 'Ibn 'Arabī, Jakarta:Gaya Madina Pratama, 1989.

Ali, Yunasril, Manusia Citra Ilahi: Pengenmbangan Konsep Insan Kamil Ibn 'Arabī oleh al-Jili, Jakarta: Paramadina, 1997.

Siraj, SaidAqil, Tasawuf Sebagai Kritik Sosial, Bandung: Mizan, 2006.

Hidayat, Komarudin, Tragedi Raja Midas: Moralitas Agama dan Krisis Moderisme, Jakarta: Paramadina, 1998.

Ibn 'Arabī, Muhyyi al-Dīn, Fuṣūṣ al-Hikam, Beirūt: Dār al-Kutub al'Alāmiyah, 2003.

Ibn 'Arabī, Muḥyi al-Dīn, Aḥkām al-Qur'ān, Beirūt: Dār alMa'rifah, vol 4, tt.

Ibn 'Arabī, Muhyyi al-Dīn, Futūḥat al-Makkiyah, Bairut: Dar al-Kutub al-Alamiyah, 2006

Ibn 'Arabī, Muhyi al-Dīn, Sajarat al-Kauwn, Riyaḍ: Riyaḍ'Abdillāh, 1957.

Kartanegara, Mulyadi, Menyelami Hakikat Tuhan, Manusia dan Alama, Jakarta:Erlngga,2007.

Keraf, Sony, Etika Lingkungan, Jakarta: Kompas, 2006.

Murata, Sachiko, Kearifan Sufi dari Cina, Yogyakarta: Kreasi Wacana, 2003.

Nasr, Seyyed Hossein , Islam dan Krisis Lingkungan, Islamika, No. 3, Januari-Maret 1994

Nasr, Seyyed Hossein, Living Sufsm, London: Mandala Books, 1980.

Nasr, Seyyed Hossein, Religion and The order of Nature, New York: Oxford University Press 1996,

Nasr, Seyyed Hossein, The Encounter Man and Nature, California:California Press, 1984. 


\section{PETUNJUK PENULISAN ARTIKEL}

Noer, Kautsar Azhari, Ibn Ibn 'Arabī: Wahdatul Wujud dalam Perdebatn, Jakarta: Paramadina, 1995.

Rahman, Luthfi, Etika Perdamaian Islam: Telaah atas Pemikiran Maulana Wahiduddin Khan, Thesis S2 IAIN Walisongo, 2012.

Suwito, Eko-Sufisme: Konsep, Strategi dan Dampak, Yogyakarta: STAIN Press, 2011,

Palmer, E Ricard, Hermeneutika: Teori Baru Mengenai Interpretasi, terjemah Damanhuri Manmud, Yogyakarta: Pustaka Pelajar, 2005

Schimel, Annemarie, Dimensi Mistik Dalam Islam, Jakarta: Pusataka Firdaus, 1986.

Sumaryono, E, Hermeneutik: Sebuah Metode Filsafat, Jakarta: PT Raja Grafindo Persada, 1999.

Tailor, W Paul, Respect for Nature, New Jersey: Universiti Press, 2011

Takesita, Masatake, Insan Kamil: Pandangan Ibn 'Arabī, Surabaya: Risalah Gusti, 2005,

White, Lynn Jr, The Historical Roots of Our Ecologic Crisis, dalam Science, Volume 155, Number 3767, 10 March 1967. 



\section{INDEKS ISTILAH PENTING}

A

'amal 238

Ahlu al-Sunnah 9

Ahlu al-Sunnah wa al-Jamā'ah 197

al-kasb (acquisition, perolehan) 47

Alkitab 133

al-yasar al-Islāmī 6

Asketisme 13

Ateisme 218

C

Cinta 92

D

Deisme 216

E

Epistemologi 11

Ethic 237

$\mathbf{F}$

Falsafah 92, 130

Fitrah 107, 145

free will (kehendakbebas) 45

G

God 133, 134

H

Hizmet 49

human dignity 74

Iblis 153, 154

Ilmu kalam 10 
ilmu tauhid 10

Imām Mubīn 53, 54

Islamisasi kultur Jawa 198

J

Jalan Tasawuf 106

jihād 16

$\mathbf{K}$

kebebasan 47, 48

khalïfah 7, 14, 249

Kitāb Mubìn 54

$\mathbf{L}$

Lauḥ Maḥūz 53

M

Mazhab Salaf 9

Mistisisme 261

Modernisme 115

Monotheisme radikal 75, 77, 78, 86

mutual comunication 11

$\mathbf{N}$

nilai moral 126

$\mathbf{P}$

persamaan 83

$\mathbf{R}$

Revitalisasi Turaś 9

RisālahTauḥìd 10

S

Seni 91, 92

skripturalis 75

spekulatif-fatalisme 12

substansialis 75 


\section{INDEKS}

$\mathbf{T}$

takdir aktual 45

takdir formal 54

Tasawuf 46

Tauhid 9, 10

teologi 5

Teologi Islam 6, 25, 45

teologi modern 113

teologi praktis $5,8,11$

$\mathbf{U}$

Utilitarianisme 16

V

vertical spiral 11

$\mathbf{Z}$

Zionisme 178 



\section{PETUNJUK PENULISAN ARTIKEL}

1. Artikel merupakan tulisan konseptual atau hasil penelitian studi keislaman yang belum pernah diterbitkan dalam media cetak atau jurnal lain dengan fokus bahasan: al-Quran dan hadis; tasawuf/mistisisme Islam dan akhlak; filsafat Islam; ilmu kalam/teologi Islam; dan perbandingan agama.

2. Artikel ditulis dalam bahasa Indonesia yang baku atau bahasa Inggris dengan spasi 1,5 cm di atas kertas A4 dengan margin atas $(3,5 \mathrm{~cm})$, bawah $(3,5 \mathrm{~cm})$, kanan $(3,5 \mathrm{~cm})$, dan kiri $(3,5 \mathrm{~cm})$ dengan menggunakan huruf/fontCambria ukuran $12 \mathrm{pt}$, kecuali pada kutipan langsung dan catatan kaki (footnote) ukuran $10 \mathrm{pt}$.

3. Artikel konseptual meliputi judul, nama dan identitas penulis, abstrak dalam bahasa Inggris dan Indonesia (100-250 kata), kata-kata kunci (5-10 kata), pendahuluan, isi atau pembahasan, penutup, dan daftar pustaka.

4. Nama penulis (tanpa gelar akademik, jabatan, atau kepangkatan) dicantumkan disertai alamat korespondensi (alamat lembaga), alamat e-mail, dan/atau nomor telepon kantor, rumah atau telepon seluler.

5. Artikel dikirim dalam bentuk cetak (print out) sebanyak 1 eksemplar beserta $\mathrm{CD}$, atau dikirim melalui e-mail ke alamat: jurnalteologia@yahoo.com. Panjang tulisan 15-25 halaman. Artikel diserahkan paling lambat dua bulan sebelum jurnal diterbitkan.

6. Kata dari bahasa asing dan bahasa daerah yang belum terbakukan dalam Kamus Besar Bahasa Indonesia (KBBI) ditulis dengan cetak miring (italic); khusus teks Arab ditulis dengan huruf/font Traditional Arabic ukuran 14 pt, sedangkan transliterasi kata-kata Arab menggunakan huruf/fontcambria dicetak miring (italic) dan mengikuti pedoman Jurnal Teologia. 
7. Artikel yang memenuhi syarat diseleksi dengan melibatkan mitrabebestari dan diedit penyunting untuk penyeragaman format dan gaya penulisan tanpa mengubah isinya.

8. Penulisan catatan akhir (endnote) dan daftar pustaka sebagai berikut:

\section{a. Catatan Akhir}

${ }^{1}$ Budhy Munawar-Rachman, Reorientasi Pembaharuan Islam: Sekularisme,Liberalisme dan Pluralisme Paradigma Baru Islam Indonesia, Jakarta: Paramadina, 2010, h. 33.

2Zachary Abuza, Militant Islam in Southeast Asia: Crucible of Teror, Collorado: Lynne Rienner Publisher Inc, 2003, h. 69.

Untuk pengutipan ulang: maksimal 3 kata

${ }^{3}$ Budhy Munawar Rachman, Reorientasi Pembaharuan, h. 183.

Atau, jika buku tersebut judulnya tunggal:

4Budhy Munawar Rachman, Reorientasi, h. 191.

5Ibid., h. 184.

${ }^{6}$ Zachary Abuza, Militant Islam, h. 70.

${ }^{7}$ M. Amin Abdullah, "Dialektika Agama antara Profanitas dan Sakralitas", dalam Moh. Shofan [ed.], Jalan Ketiga Pemikiran Islam Mencari Solusi Perdebatan Tradisionalisme dan Liberalisme, Yogyakarta: IRCiSoD, 2006, h. 12.

${ }^{7}$ Muhạmmad Shaḥūr, al-Islām wa al-Īmān: Manẓumāt al-Qiyām, Damaskus: Ahālī,1996, h. 100.

8David Commins, "Syria" dalam The Oxford Encyclopedia of The Modern Islamic World, ed. John L Esposito, New York: Oxford University Press, 1995, h. 158159.

\section{b. Daftar Pustaka (ditulis urutan abjad)}


Abdullah, M. Amin, "Dialektika Agama antara Profanitas dan Sakralitas", dalam Moh. Shofan [ed.], Jalan Ketiga Pemikiran Islam Mencari Solusi Perdebatan Tradisionalisme dan Liberalisme, Yogyakarta: IRCiSoD, 2006.

Abuza, Zachary, Militant Islam in Southeast Asia: Crucible of Teror, Collorado: Lynne Rienner Publisher Inc, 2003.

Commins, David, "Syria" dalam The Oxford Encyclopedia of The Modern Islamic World, ed. John L Esposito, New York: Oxford University Press, 1995.

Rachman, Budhy Munawar, Reorientasi Pembaharuan Islam: Sekularisme,Liberalisme dan Pluralisme Paradigma Baru Islam Indonesia, Jakarta: Paramadina, 2010.

Shahrūr, Muḥammad, al-Islām wa al-Īmān: Manẓumāt alQiyām, Damaskus: Ahālī,1996.

9. Penulisan artikel dalam Jurnal Teologia ini menggunakan pedoman transliterasi Arab-Indonesia sebagai berikut:

\begin{tabular}{|c|c|c|c|c|}
\hline No & Arab & Indonesia & Arab & Indonesia \\
\hline 1 & 1 & $\mathrm{a}$ & ض & d \\
\hline 2 & ب & $\mathrm{b}$ & $b$ & $t$ \\
\hline 3 & ت & $\mathrm{t}$ & ظ & $\mathrm{z}$ \\
\hline 4 & ث & $\dot{\mathrm{S}}$ & $\varepsilon$ & ‘ \\
\hline 5 & ج & $\mathrm{j}$ & $\dot{\varepsilon}$ & gh \\
\hline 6 & $\tau$ & $\mathrm{h}$ & ف & $\mathrm{f}$ \\
\hline 7 & $\dot{\tau}$ & $\mathrm{kh}$ & ق & $q$ \\
\hline 8 & 2 & $\mathrm{~d}$ & 5) & $\mathrm{k}$ \\
\hline 9 & j & $\dot{\mathrm{Z}}$ & $J$ & l \\
\hline 10 & ر & $r$ & b & $\mathrm{m}$ \\
\hline
\end{tabular}


PETUNJUK PENULISAN ARTIKEL

\begin{tabular}{|c|c|c|c|c|}
\hline 11 & $j$ & $\mathrm{z}$ & $j$ & $\mathrm{n}$ \\
\hline 12 & $\omega$ & $\mathrm{s}$ &, & $\mathrm{W}$ \\
\hline 13 & ش & sy & $ه$ & $\mathrm{~h}$ \\
\hline 14 & $\omega$ & $s$ & $\mathrm{~s}$ & $\mathrm{y}$ \\
\hline
\end{tabular}

Untuk menunjukkan bunyi hidup panjang (madd) dengan menuliskan coretan horizontal (macron) di atas huruf $\bar{a}, \bar{\imath}$ dan $\bar{u}$. Bunyi hidup dobel (dipthong) Arab ditransliterasikan dengan menggabungkan dua huruf "ay" dan "aw", seperti layyinah, lawwamah. Untuk kata yang berakhiran ta' marbuțah dan berfungsi sebagai șifah (modifier) atau muḍ̄âf ilaih ditransliterasikan dengan "ah", sedang yang berfungsi sebagai muḍāf ditransliterasikan dengan "at".

$$
\begin{array}{ll} 
& \text { żawī al-furūḍ } \\
& \text { ahlu al-sunnah }
\end{array}
$$

Untuk singkatan dengan maksud penghormatan atau pengagungan ditulis dengan huruf kecil.

swt : subḥānahu wa ta'ālā; Allah swt : Allah subḥānahu wa ta'ālā

saw : șalla Allāhu 'alaihi wa sallam; Nabi Muhammad saw.: Nabi șalla Allāhu 'alaihi wa sallam.

ra : raḍiya Allāhu 'anhu; Ali ra.: Ali raḍiya Allāhu 'anhu

as : 'alaihi as-salām; Nabi Adam as.: Nabi Adam șalla Allāhu 'alaihi wa sallam

kw : karama Allāhu wajhah; Ali kw.: Ali Allāhu wajhah.

Untuk kutipan surah al-Quran, nama al-Quran ditulis disesuaikan dengan bacaan kata aslinya dan disertai dengan padanan nomor surat: QS. al-Baqarah [2]: 100; QS. al-A'rāf [7]: 150. 